\title{
MMP9 wt Allele
}

National Cancer Institute

\section{Source}

National Cancer Institute. MMP9 wt Allele. NCI Thesaurus. Code C49736.

Human MMP9 wild-type allele is located within 20q11.2-q13.1 and is approximately $8 \mathrm{~kb}$ in length. This allele, which encodes matrix metalloproteinase- 9 protein, plays a role in the breakdown of the extracellular matrix via the degradation of both gelatins (types I and V) and interstitial collagens (types IV and V). The MMP9 gene is associated with neoplasm invasiveness. 